\title{
Intellectual Evolution of Georg Lukács in the Context of Developing Lenin's Idea of Revolution ${ }^{1}$
}

\author{
BETTINA SZABADOS \\ Research Centre of Humanities, Institute of Philosophy, 4 Tóth Kálmán Street, Budapest, 1097, Hungary; \\ Doctoral School of Philosophy, Eötvös Loránd University, Múzeum krt. 4, Budapest, 1088, Hungary \\ Email: szabados.bettina@btk.mta.hu
}

\author{
ALEKSANDR SAUTKIN \\ Department of Philosophy, Social Sciences and Social Security Law, Murmansk Arctic State University, 15 Kapitana Egorova Street, \\ Murmansk, 183038, Russia \\ Email: sautkin72@mail.ru
}

\begin{abstract}
The Hungarian philosopher, Georg Lukács, recognized the crisis-consciousness of his generation at the turn of the 20th century and began to search for solutions in the art. However, his theory about art proved to be illusory, being unable to reshape society. After many philosophical attempts to realize his theory in praxis, in 1918 Lukács turned to Marxism and later became one of the most influential Marxist thinkers of his time. In 1919, when the Hungarian Soviet Republic fell, Lukács, like many other intellectuals, had to flee abroad. In emigration, he started to summarize the experiences of the fallen revolution and referred to Lenin's ideas in his early Marxist works, in 'History and Class Consciousness' (1923) and 'Lenin: A Study on the Unity of his Thought' (1924). This paper aims to follow Lukács' path, how he became a Marxist from an Essayist, and what solutions he found for the social crises of his era.
\end{abstract}

Keywords: Georg Lukács, Vladimir Lenin, Marxism, theory and praxis, sacrifice, redemption, revolution

\section{INTRODUCTION}

The 150th anniversary of the birth of V. I. Lenin gives an occasion to rethink his influence, especially on the (Central)-European thought. Some philosophers, interested in Lenin's ideas, became leading figures, like Georg Lukács, the later well-known Marxist theorist. At

1 The research was funded by RFBR and FRLC, Project No. 20-511-23002. Some of the points that formed the basis of this article were presented at the international scientific conference 'Modern Civilization, Capitalism, and Social Justice (for the 150th Anniversary of Vladimir Lenin)' held at the Sociological Institute of the Russian Academy of Sciences (Saint Petersburg, 1-3 October 2020). 
the beginning of the 1900s, he was 'just' a talented young thinker, who recognized the deep social problems of his milieu and was seeking solutions in his early essays.

Lukács began his career in an uncertain era and searched for a ground, where his philosophy would be 'accepted'. At the beginning of the 1910s, he tried to build an academic carrier: his idea was to habilitate in the Ruprecht Karl University of Heidelberg, but his application was denied. Thereafter, Lukács was already in Budapest and taking part in the Hungarian Soviet Republic. ${ }^{2}$

During his theoretical developing Lukács got to know only later Lenin's works, as he refers to them in his biographical writing 'Gelebtes Denken' (see Lukács 1989: 64). According to Lukács, after the collapse of the Hungarian Soviet Republic (already in emigration in Vienna) he got the chance to know Lenin's praxis better. So, the main interest of this paper can be summarized with the following questions: What significance did Lenin's theory have for Lukács? How did Lukács interpret Lenin's idea on theory and praxis (especially on revolution) in the mirror of the fallen Hungarian Soviet Republic? To find answers to these questions, it is necessary to follow and reconstruct the young Lukács' development of thinking. Our analysis is conducted in the field of comparative studies that comprehend the migration of ideas and their transformations when crossing political and cultural boundaries, as well as the boundaries of discourses. A comparative historical approach is used, combined with some hermeneutic procedures and analysis of cross-cultural influences.

We tend to see Lukacs not so much as a follower of Lenin or a developer of Lenin's version of Marxism but as the creator of Western (Hegelian) Marxism. Yet Lukács is sometimes considered the 'ultimate philosopher of Leninism' (Žižek 2000: 179).

In the past few years, interest in the legacy of Lukács and his reflection on Lenin has not waned. A number of publications are devoted to comprehending the thoughts of Lukács expressed in 'History and Class Consciousness', as well as their adaptation to the new socio-political conditions of the 21st century (see, for example, Fuchs 2020; Jay 2018; Burman 2018).

\section{THE YOUNG GEORG LUKÁCS AND THE INTELLECTUAL LIFE OF THE EARLY 20TH CENTURY}

Being born and grown up in the Austro-Hungarian Empire, Georg Lukács had to face early the social problems of the monarchy. At the turn of the century, the rapid social and economic changes sharpened the vulnerability of the individuum (Földényi 1980: 18) and evoked the crisis-consciousness (Krisenbewusstsein) of Lukács' generation. This phenomenon was represented clearly in Arthur Schnitzler's play 'La Ronde' (the original German name is 'Reigen'), written around 1900 and representing class ideology and the boundaries of different social classes. The young Lukács strongly criticized this objectification, where certain individuals can be easily replaced. In one of his very first works 'The Sociology of Modern Drama' (in Hungarian 'A modern drama fejlódésének története'), completed and published in 1909, he summarizes the process of objectification as it can be observed in the process of the modern division of labour:

'The relation between labor and laborer always becomes more incoherent: the laborer shows less and less his personality in the labor, and then again the labor requires less and less the specific individuality of those who accomplish it. The labor will have separate, objective life against the individuality of the particular individual, and his individuality has to express

\footnotetext{
2 For more information about the young Lukács' academic and political possibilities see Szabados 2020.
} 
itself somewhere else, despite the actual activity, what he is already doing $\langle\ldots\rangle$. The correlation between persons also becomes more impersonal' (Lukács 1978: 105-106). ${ }^{3}$

The young Lukács is often 'accused' by the later canon that he shows a sign of romantic anticapitalism when he claims an aesthetic value to the labour, where the individuality of the labourer is an important factor. But as Judith Butler points out:

'On the contrary, he argues that, for expression to communicate, and so to mediate between the authentic impulse of the creator and the social conditions within which the creator works, an enabling form has to be found or created' (Butler 2010: 2).

So, the young Lukács was sensible to the social problems of his era and constructed them into a philosophical problem. Nothing proves this more than his collection of essays, 'Soul and Form' (in Hungarian 'A lélek és a formák'), where he claims the priority of the form. Lukács had probably been influenced by Georg Simmel, ${ }^{4}$ who pointed out that society can be observed in the always-changing relations (see Hidas 2019: 38). In one of his early writing Lukács strongly criticized Simmel, calling him the 'true philosopher of the impressionism' who just observes the forms of life, without solving problems, without constructing never-changing eternal forms (see Lukács 1977: 747).

It is clear now that Lukács sought for a certain ground, where the category of virtues is clear, and the so-called subject-object relations (Subjekt-Objekt Beziehung) are parallel with each other. Lukács idealized the ancient Greeks and referred to them not just in 'Soul and Form' but also in 'The Theory of the Novel', stating that they had a pure world of forms (see Lukács 1997: 27-29; Lukács 1975: 493). In the 'closed' Greek culture the will of the soul and the action were the same, and there was no need for philosophy in those 'happy ages' because philosophy is the sign that the relationship between the immanent and the transcendent has been broken. Lukács cites Novalis when he says that philosophy is homesickness and its true mission is to map that transcendental place to find the way back to the immanent (ibid.). How can we find the way back to those 'happy ages'? According to Lukács' 'Soul and Form', the forms are the possible answer to this question.

The forms are bringing order in the always-changing experience, they are as a closed unity' representing the relation between subject and object. The literary forms, as they are represented in 'Soul and Form', have a requirement to express reality and besides that '[the] forms permit or engender a certain kind of expressivity, one that would be impossible without them' (Butler 2010: 4). However, Lukács gives specific importance not just to the idea of form, but to the essayist himself, who is neither a poet nor a scholar, and certainly not a philosopher: he is a critic, but he has not fought by himself for the right to criticize. Although he has the measurement of the criticism, he is not capable to construct it alone. The measurement of the critic comes from 'the great value-definer of aesthetics' (Lukács 2010: 32).

'The essayist is a Schopenhauer who writes his Parerga while waiting for the arrival of his own (or another's) The World as Will and Idea, he is a John the Baptist who goes out to preach in the wilderness about another who is still to come, whose shoelace he is not worthy to untie' (ibid.).

According to Lukács, the essayist will have the position of a prophet, who propagates the arrival of a messiah, because modernity is only the era of perfect sinfulness (Vajda 1997:

3 The original Hungarian text is quoted in our English translation.

${ }^{4}$ Lukács got in contact with Georg Simmel after his peregrination in Berlin in 1906. He also mentioned Simmel's influence on his development in his Curriculum vitae, which he submitted to the Faculty of Philosophy of the Ruprecht Karl University Heidelberg (see Sauder 1984: 98-99). 
347-348), which must be redeemed. The early essays and theoretical works like 'The Philosophy of Art' (1912-1914) and the 'Aesthetic' (1914-1916) or 'The Theory of the Novel' (1916-1918) are a search for the possibilities of redemption through art and Hegel's philosophy of history, only to come to the idea of the revolution.

\section{THE CONCEPTS OF SACRIFICE AND REDEMPTION IN LUKÁCS' PHILOSOPHY}

Lukács' choice to be a Marxist as an important moment in his theoretical development has been analysed in the canon. Therefore, there must be only mentioned how Lukács struggled to find a way between theory and praxis. This effort is accentual in the essay about Kierkegaard and Regine Olsen and in the dialogue 'Von der Armut am Geiste' (in Hungarian 'A lelki szegénységröl'), ${ }^{5}$ where Lukács, on the grounds of Kierkegaard's ethic, searches for the possibility to form the life itself. Kierkegaard's choice to leave Regine Olsen was a necessary sacrifice, according to Lukács, in order to save not just Regine, but Kierkegaard too. Kierkegaard is determined to create and, therefore, he cannot let himself be blinded by life, he must become an ascetic. Lukács described Kierkegaard's choice as a leap between the aesthetical, ethical and religious spheres, that is possible with the necessary sacrifice only. However, Lukács is doubtful whether Kierkegaard's gesture (or sacrifice) has brought redemption for the gesture always had the possibility to break the form and have a common understanding, despite that, the death is unchangeable and cannot be understood otherwise. It could give an ending and it could freeze the form, but even death is not capable to create form against life and this is the tragedy of Kierkegaard (Lukács 2010: 57-58). Kierkegaard's gesture and leap leave the questions open and give the chance to search for other paths and spheres and this is what Lukács did. Wanting to avoid Kierkegaard's tragedy, Lukács was determined to have not just immanent redemption, but transcendent one, therefore he chose the 'detour of ethic' (Hévizi 2015: 281-285). ${ }^{6}$

The idea of the detour has already a sign in Lukács' writing 'Von der Armut am Geiste', where the biblical story of Mary and Martha is mentioned (Lukács 1977: 542-543). Mary chose to be close to Jesus leaving the practical work behind, while Martha is preparing everything else. Mary will have redemption because she can leave the necessity of this life behind, but those, who do not have the capability of this pureness, have to work for the redemption, they cannot just have it - this is the idea of the 'Werkethik', according to Lukács. This means, however, that the 'creation of the redemption' is an action, and the redemption always needs a sacrifice (Hévizi 2015: 288). Lukács was not seeking immanent redemption only, therefore the first sphere, the aesthetical one (where the artworks as a closed-form can bring immanent comprehension about the changing life) proved to be a diabolic temptation. The leap through the ethical and religious spheres is not possible for Lukács, because, according to the story of Mary and Martha, he is not capable of immanent redemption, his commitment is to work for immanent and transcendent redemption. The sacrifice here is the commitment to sin (ibid.). However, in 'Bolshevism as a Moral Problem' (first published in Szabadgondolat in December 1918), Lukács claims that only a long process can bring order, where the soul is hardened

5 This work was first published in Hungarian (translated from German by Béla Balázs) in the Szellem journal in 1911, No. 2. p. 202-214. The original German text was published next year (in 1912) in the Neue Blätter journal, No. 5/6, p. 67-92.

6 Ottó Hévizi has given so far the most precise comprehension of Lukács' ethic, so the authors of this paper rely on his conception about Lukács' 'detour of ethic' (in Hungarian 'a kerülöút etikája') (see Hévizi 2015: 276-295). 
in the long fight (Lukács 2002). For Lukács, the truth is not possible with lies, as well as the good cannot come from the bad, and this creates an irresolvable moral problem (ibid.). A few months later, in 1919, Lukács publishes his 'Tactics and Ethics' (in Hungarian 'Taktika és etika'), where he describes the necessity of the sin and its acceptance.

'It is not the task of ethics to invent prescriptions for correct action, nor to iron out or deny the insuperable, tragic conflicts of human destiny. On the contrary: ethical self-awareness makes it quite clear that there are situations - tragic situations - in which it is impossible to act without burdening oneself with guilt' (Lukács 1972).

By that time Lukács was already a People's Commissar for Education and Culture in the Party of Communists in Hungary and his leap was a riddle not just for his contemporaries, ${ }^{7}$ but also for his 'interpreters.' However, Lukács' choice had to be a sacrifice in order not to be only a gesture, like Kierkegaard's leap. Without sacrifice, a gesture stays a gesture and it could not bring any real solution. What nature Lukács' sacrifice had and what his real sacrifice was, is an open question. What concerns us in this paper, is that the sacrifice, in the sense of taking the sin to create a 'higher order', is the core of the ethic of Bolshevism. It was strongly influenced by the idea of messianism, which believes that redemption is only possible through destruction (see Scholem 1995: 1-4). The year 1917/1918 was a historical moment not just in Lukács' life but in the European history of ideas as well. Lukács states in his biographical work that his thinking had changed entirely, and his choice had determined his way of living (Lukács 1989: 62). According to Lukács, the guiltiness is a necessary element of the rightful praxis (Lukács 1989: 63), which could bring changes both for the society and individuality. As Lukács wrote about the theoretical and practical development:

'No one recognized it - just (in a certain sense) Lenin - that the two processes, as a matter of fact, are the same from the aspect of world-history, i.e. the social born of the new human comes from the synthesis of every individual effort, which aim is to face a new reality honestly and revolutionary' (Lukács 1977: 65). ${ }^{8}$

\section{RETHINKING LENIN AND THE IDEA OF REVOLUTION IN LUKÁCS' PHILOSOPHY}

It is clear that Lenin had no serious influence on Lukács' choice to join the Party of Communists in Hungary, it was rather Lukács' ethical dilemma. By 1919, Lukács had not been much familiar with Lenin's ideas (Lukács 1977: 66). After the fall of the Soviet Republic in Hungary, Lukács fled to Vienna, where he began his 'Marxist Studies' and started to explore Lenin's theory. In 1923 Lukács summarized the experience of the revolution in his most well-known work 'History and Class Consciousness': his idea was to establish the ground of the revolution and the dictatorship of the proletariat in the culture, besides that Lukács' intention was to merge Lenin's idea on revolution into Marxism. ${ }^{9}$ In the 1920 s Lukács was rather a publicist than a philosopher, however, in 1924 he published one bigger work about Lenin, the title of which was 'Lenin: A Study on the Unity of his Thought', and several smaller texts, for example, prefaces for Lenin's writings. In these works, Lukács points out that Lenin prepared not just the possibility of the Russian revolution, but the possibility of a world-revolution (see Lukács 2009).

7 See Max Weber's letter from February/March 1920, where Weber wrote Lukács that their political convincement separates them from each other (in Max Weber-Schäfer, Deponat BSB München, Ana 446).

8 The original Hungarian text is quoted in our English translation.

9 For further interpretations about Lukács' study on Lenin’s thought see Somlai 1970; Csunderlik 2018. 
We will assume that by 1919 Lukács had already passed the initiation from a theoretical dilemma expressing doubt about the correctness of the Bolshevik ethical postulate, to revolutionary practice without any doubt arising from the acceptance of 'tactics' as a necessary sacrificial act.

Writing a book about Lenin, Lukács formulates his general task already in the title - to reveal the deep underlying interconnection of key Leninist ideas. Lukács believes that the core of Lenin's thought is the 'actuality of the revolution' which determines the basic tonality of the entire era and acts as the most important condition for the formation of theory (i.e. historical materialism) as a practically demanded and practically working instrument. ${ }^{10}$ The deep coherence of Lenin's thinking consists of his ability to grasp problems not isolated and segmental, but holistically, which makes him congenial to Marx who 'always pictured capitalist development as a whole. This enabled him to see both its totality in any one of its phenomena, and the dynamic of its structure' (Lukács 2009: 10). This 'totality', 'the all-pervasive supremacy of the whole over the parts' is the leading methodological principle of the Marxist approach to understanding historical reality, and this principle is Hegelian at its core (Lukács 1971: 27-28).

For Lukács in his Vienna period, the idea of the Revolution becomes a way to bring totality not only to thinking (theory) but also to maintain totality as the basis of praxis. Praxis must also become total to fully correspond to the historical moment that is determined by the reality (and effectiveness!) of the Revolution. The unity of 'history and thought' should practically take place in the complete mastery of one's power - in acquiring one's class consciousness.

According to Lukács, there can be no ideological self-growth of the proletariat into their revolutionary mission, it requires a party with a strictly centralized organization, which includes the most conscious elements of the proletariat, and all these organizational relationships are also determined by the fact of the actuality of the revolution. Lukács writes: 'The Bolshevik concept of party organization involved the selection of a group of single-minded revolutionaries, prepared to make any sacrifice, from the more or less chaotic mass of the class as a whole'. And further: 'The Communists $<\ldots>$ are $<\ldots>$ the tangible embodiment of proletarian class-consciousness' (Lukács 1971: 25, 27).

And this driving force of revolutionary praxis never exists, but it is always becoming, no matter how paradoxical it may sound: the party is both a producer and a product, it is always in a dialectical movement. For Lukács, the completion of the outcome of the uncertainty and discontinuity of the 'crisis consciousness' is connected precisely with the formation of 'revolutionary consciousness', molded in the crucible of party discipline, ethics, and aspirations to reorganize the world. M. Lifshits wrote about Lukács' that 'his convinced and devoted communism <...> had a tinge of a certain self-denial, which is called Enstagung in Goethe's language' (Lifshits 1988).

Lifshitz defined the transitional stage in the development of Lukács' worldview (the period of 'History and Class Consciousness' and 'Lenin' publication) as 'revolutionary and Marxist gnosticism.'11 This 'dialectical gnosis' of a theory fused with action is clearly expressed in the following observation of Lukács: 'In Lenin's writings and speeches $\langle\ldots\rangle$, there is little about socialism as a completed condition. There is all the more, however, about the steps which can lead to its establishment' (Lukács 2009: 71).

${ }^{10}$ About Lenin's specific understanding of philosophy not so much as a theory but primarily as a practice of struggle for domination see Sautkin, Philippova 2019.

${ }^{11}$ About gnostic allusions in the reasoning of Lukács of the 1914-1915 period see Zemlyanoy 2009. 
The current moment, in which Lukács writes about Lenin and in which all Lenin's thinking and acting are carried out, is a messianic moment, and the leader of the Russian revolution takes on the function of the Messiah and a standard-bearer to follow. A constant motif of the book is a reminder that the revolution is the actuality, and it is already happening. As R. Westermann writes: 'But what is most striking is the eschatological tone of much of the book. Lukács repeatedly speaks in the language of end-times' (Westermann 2019: 956). This messianic-apocalyptic leitmotif is more than distinct, since Lenin's praxis of thought and thought that raises praxis to self-consciousness give hope for world-historical redemption and liberation. In the very difficult years after the collapse of the Soviet Republic in Hungary, Lukács associates 'the possibilities of final struggle of human salvation' (Lukács 2009: 11) precisely with Lenin, with his revolutionary philosophy.

Everything that happens to the concrete historical proletariat of the first quarter of the 20th century is at the same time connected with the redemption of all mankind, and this redemption must occur precisely in the form of a social revolution. This eschatological model clearly shows the Judaistic understanding of salvation as opposed to the Christian one - G. Scholem emphasized that 'Judaism, in all of its forms and manifestations, has always maintained a concept of redemption as an event which takes place publicly, on the stage of history and within the community' (Scholem 1995: 1).

We see that Lukács, in his reflections on Lenin's legacy, acquires his own view of Marxist theory and practice, which, on the one hand, ensures the completion of his transition from the early aesthetic forms of an anti-bourgeois revolt to an integral revolutionary worldview, and on the other hand, it makes it possible to reveal in Marxism itself the inner creative reserves that allow it to resist dogmatism and vulgarization.

\section{CONCLUSIONS}

Having traced the trajectory of Lukács' intellectual movement from the anti-bourgeois refined essayism of the pre-war period to the Marxist position of the early 1920s, we may state that the figure of the Essayist in Lukács is interpreted as a prophetic one: the aesthetic heralds the coming arrival of the Redeemer, but this redemption will be possible not in the realm of art but in revolutionary praxis. Lukács argues in the idea that in some decisive situations it is impossible to act without taking on sin and guilt, ought to be done as a sacrifice of oneself in the name of a higher purpose. One's private 'decency' is nothing in the highest ethical sense. Turning to the works of Lenin allowed Lukács to complete his transition to a new ideological position: Lenin's idea of the revolution allowed him to bring totality into theory and put it at the basis of praxis. The Revolution acquires in Lukács partly eschatological features, which he will later conceal and expel.

Received 4 November 2020 Accepted 1 December 2020

\section{References}

1. Burman, A. 2018. 'Back to Hegel! Georg Lukács, Dialectics, and Hegelian Marxism', in Hegelian Marxism: The Uses of Hegel's Philosophy in Marxist Theory from Georg Lukács to Slavoj Žižek, eds. A. Bartonek and A. Burman. Stockholm: Elanders, 17-34.

2. Butler, J. 2010. 'Introduction', in Soul and Form, eds. J. T. Saunders and K. Terezakis, trans. A. Bostock. Columbia University Press.

3. Csunderlik, P. 2018. 'The Specific Adjudication of a Given World Condition: The Theoretical Significance of Lenin's Practice in the Works of Georg Lukács', in The Centenary of the 1917 Russian Revolution(s): Its Significance in World History. Materials of the International Conference at the Centre for Russian Studies in Budapest May 15-16, 2017, ed. T. Krausz. Budapest: Russica Pannonicana, 167-173. 
4. Földényi, F. L. 1980. A fiatal Lukács. Budapest: Magvető.

5. Fuchs, C. 2020. 'History and Class Consciousness 2.0: Georg Lukács in the Age of Digital Capitalism and Big Data', Information, Communication \& Society. DOI: 10.1080/1369118X.2020.1759670.

6. Hévizi, O. 2015. Próbakövek. Van-e aranyszabály ércnél maradandóbb? Budapest: Kalligram.

7. Hidas, Z. 2019. A formák és az élet. Georg Simmel és a mindennapok szellemi megmentése. Available at: https://real.mtak.hu/105971/1/replika_112-05_hidas.pdf

8. Jay, M. 2018. 'Fidelity to the Event? Lukács' History and Class Consciousness and the Russian Revolution', Studies in East European Thought 70: 195-213. DOI: https://doi.org/10.1007/s11212-018-9307-3.

9. Krausz, T.; Mesterházi, M. 1985. Mü és történelem. Viták Lukács György müveiröl a húszas években. Budapest: Gondolat.

10. Lifshits, M. 1988. O vstrechah s Lukachem (On Meetings with Lukács). Available at: https://www.gutov. $\mathrm{ru} /$ lifshitz/texts/O\%20vstrechakh\%20s\%20Lukachem.htm

11. Lukács, G. 2020. Lukács György publicisztikája 1920-1929. Ed. M. Mesterházi, trans. by G. Berényi, F. Bródy, L. Illés, J. Kis, M. Mesterházi, G. Révai, F. Tallár, K. T. Vörös. Available at: https://www.lana. info.hu/lukacs-gyorgy/lukacs-gyorgy-muvei/lukacs-gyorgy-publicisztikaja-1920-1929/

12. Lukács, G. 2010. Soul and Form. Eds. J. T. Saunders and K. Terezakis, trans. A. Bostock. Columbia University Press.

13. Lukács, G. 2009. Lenin: A Study on the Unity of his Thought. Trans. N. Jacobs. London, New York: Verso.

14. Lukács, G. 1997. 'A lelki szegénységről (Egy levél és egy párbeszéd)', in Ifjúkori müvek (1902-1918). Budapest: Magvetö, 537-552.

15. Lukács, G. 1989. Megélt gondolkodás. Életrajz magnószalagon. Eds. I. Eörsi and E. Vezér. Budapest: Magvetö.

16. Lukács, G. 1978. A modern dráma fejlödésének története. Budapest: Magvetö.

17. Lukács, G. 1977. Ifjúkori müvek (1902-1918). Budapest: Magvető.

18. Lukács, G. 1975. A regény elmélete. Trans. from the German by D. Tandori. Budapest: Magvetö.

19. Lukács, G. 1971. History \& Class Consciousness: Studies in Marxist Dialectics. Trans. R. Livingstone. Cambridge, MA: MIT Press.

20. Lukács, G. 1919. Tactics and Ethics. Trans. R. Livingstone. Available at: https://www.marxists.org/archive/lukacs/works/1919/tactics-ethics.htm

21. Lukács, G. 1918. A bolsevizmus mint erkölcsi probléma. Available at: https://www.marxists.org/magyar/ archive/lukacs/bmep.htm

22. Sauder, G. 1984. 'Von Formalitäten zur Politik: Georg Lukács' Heidelberger Habilitationsversuch', Zeitschrift für Literaturwissenschaft und Linguistik 53-54: 79-107.

23. Sautkin, A.; Philippova, E. 2019. 'Lenin and Nietzsche in the Althusserian Perspective: Philosophy as Eternal Battle, Filosofija.Sociologija 3: 183-191. DOI: https://doi.org/10.6001/fil-soc.v30i3.4040.

24. Scholem, G. 1995. The Messianic Idea in Judaism: And Other Essays on Jewish Spirituality. New York: Schocken Books.

25. Somlai, P. 1970. Lenin és a magatartás forradalma: Lukács György: Lenin c. könyvéröl. Available at: https://real-j.mtak.hu/5368/1/Kritika_1970.pdf\#page=383

26. Szabados, B. 2020. 'Georg Lukács in Heidelberg: A Crossroad between the Academic and Political Career', Filozofia 75(1): 51-64. DOI: https://doi.org/10.31577/filozofia.2020.75.1.1.

27. Vajda, M. 1997. 'A tökéletes bűnösség korszaka?' in A Budapesti Iskola II. Tanulmányok Lukács Györgyröl, Márkus György-Vajda Mihály, ed. A. Kardos. Budapest: Argumentum, 347-368.

28. Westermann, R. 2017. 'From Myshkin to Marxism: The Role of Dostoevsky Reception in Lukács's Revolutionary Ethics', Modern Intellectual History 16(3): 927-960. DOI: https://doi.org/10.1017/ S1479244317000373.

29. Zemlyanoy, S. N. 2009. 'Dobrota kak eskhatologicheskaya kategoriya. 1-ya i 2-ya etiki v perepiske Georga Lukacha i Paulya Ernsta (Kindness as an Eschatological Category. 1st and 2nd Ethics in the Correspondence Between Georg Lukács and Paul Ernst), in Ethical Thought: Contemporary Research, ed. A. A. Guseynov. Moscow: Progress - Traditsiya, 306-328.

30. Žižek, S. 2000. 'Postface: Georg Lukács as the Philosopher of Leninism', in A Defence of History and Class Consciousness: Tailism and the Dialectic, ed. G. Lukács, trans E. Leslie. London: Verso, 151-182. 
BETTINA SZABADOS, ALEKSANDR SAUTKIN

\title{
Georgo Lukácso intelektinė evoliucija plètojant Lenino revoliucijos idèją
}

\begin{abstract}
Santrauka
Vengrų filosofas Georgas Lukácsas XX a. pr. matè savo kartos sąmonès krizę ir leidosi ieškoti sprendimų mene. Tačiau jo meno teorija pasirodè esanti iliuzinė, nepajègi pertvarkyti visuomenès. Po daugelio filosofinių pastangų igyvendinti savą teoriją praktiškai, 1918 m. G. Lukácsas pasuko link marksizmo ir vèliau tapo vienu ịtakingiausių to meto marksistų mąstytojų. 1919 m., žlugus Vengrijos sovietų respublikai, G. Lukácsui, kaip ir daugumai kitų intelektualų, teko bègti ị užsienį. Emigracijoje parašytuose ankstyvuosiuose marksistiniuose darbuose - Istorija ir klasiné sąmoné (1923) ir Leninas: studija apie jo minties vienove (1924) - jis apibendrino žlugusios revoliucijos patirtis, apeliuodamas ị Lenino idèjas. Straipsnyje atskleidžiama, kaip eseistas tapo marksistu ir kokius to laiko socialinių krizių sprendimus jis rado.
\end{abstract}

Raktažodžiai: Georgas Lukácsas, Vladimiras Leninas, marksizmas, teorija ir praktika, auka, atpirkimas, revoliucija 